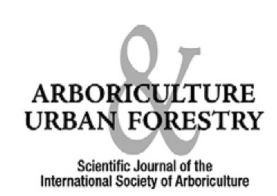

\title{
Landslides and the Urban Forest
}

\author{
Robert E. Loeb and Samuel King
}

\begin{abstract}
Trees and saplings were felled and killed by rockslides and soil slides formed during the record breaking rains of May 1-2, 2010, in Radnor Lake State Natural Area, Nashville, Tennessee, U.S. The losses were analyzed by species; stem basal area; root plate diameter and depth; percent slope; occurrence in a rockslide or soil slide as well as species classification as a lateral root system species versus tap or heart root system species. The number of stems lost for each species had a distribution similar to the results of the 2009 Natural Area survey but the number of saplings was significantly underrepresented at the landslide sites. Tree deaths were nearly five times greater than saplings lost. Although there were nearly equal numbers of tree and sapling stems classified as possessing a lateral root system versus tap or heart root system, $74 \%$ of the sapling losses were from surface root system species. The means for root plate diameter and depth were significantly larger in rockslides than soil slides even though the mean stem basal area did not differ significantly. For both slide types, slope steepness was not correlated with root plate depth, root plate diameter, or stem basal area. Similarly for both root system classifications, slope steepness was not significantly correlated except for surface root system trees with root plate depth. Planting tap root system trees reduces the risk of landslide, but advances in the cultivation of taxa, such as hickory (Carya spp.), are needed to assure tap root preservation during transplantation.

Key Words. Rockslide; Root Plate; Root System; Soil Slide; Torrential Rain; Urban Trees.
\end{abstract}

Research on the relationships between forests and landslides indicates tree roots reduce the risk of hydrogeomorphic hazards (Sakals et al. 2006). Extreme rainfall has the greatest effect on soil slides because soil moisture is inversely related to soil cohesion and plasticity, and the forces created by surface and subsurface flow from extraordinary rainfall contributes to soil movement (Wu and Chen 2009). In shallow soils ( $<0.7 \mathrm{~m}$ depth), soil cohesion is enhanced by roots forming vertical anchors and dense lateral networks (Johnson and Wilcock 2002). Also, trees modify the soil moisture regime through increased evapotranspiration (Greenway 1987), and species with deeper roots sustain higher transpiration for longer periods than shallowly rooted species (McNaughton and Jarvis 1983). Roots form macropores that connect to create hydrologic drainage networks in deep soils. The development of high pore water pressures associated with slope failures is lessened though the drainage networks except in the situations of macropore termination or convergence, which concentrates subsurface drainage (Sidle and Ochiai 2006). In regard to rockslides, the combination of roots penetrating and separating rock fissures and roots binding rock fragments has a variable effect on the generation of hydrostatic pressure and uplift pressure on rock under intense rainfall conditions (Perret et al. 2004).

Although damage to structures and roads caused by landslides is far more common in urban than rural areas, the focus of research on forests and landslides has been in planted rural forests that are harvested for timber (Sakals et al. 2006; Sidle and Ochiai 2006). The literature review for this study revealed that studies of the effects of landslides on the species composition of forests have not been performed. In contrast to single species timber plantings in rural areas, changes in species composition following landslides is important for urban areas because a far greater variety of spe- cies are planted or retained from pre-urban development forests. Selection of species for plantings and retention of existing trees in landslide-prone urban areas is important to arboriculture and urban forest management and gives rise to research questions in regard to urban tree species and landslides. Do rockslides or soil slides change the species composition of trees and saplings in urban forests? Are the diameter and depth of the root plate different for urban trees killed in soil slides versus rockslides? Are surface root systems species affected differently by urban landslides than species with tap root and heart root systems? These three research questions were examined for landslides in the urban forests of Radnor Lake State Natural Area, Nashville, Tennessee, U.S.

\section{MATERIALS AND METHODS}

\section{Site Description}

Radnor Lake State Natural Area is located just south of downtown Nashville, TN $\left(36^{\circ} 03^{\prime} \mathrm{N}, 86^{\circ} 47^{\prime} \mathrm{W}\right)$ and is within the Otter Creek Watershed that encompasses south-central Davidson and north-central Williamson counties, in Tennessee. The 473 ha tract is in the western mesophytic forest region (Braun 1950) and became Tennessee's first State Natural Area in 1973. Miller and Wiethe (1975) have described how abnormally high rainfall culminated in near record floods during March 11-13, 1975 and initiated numerous colluvium landslides in the Otter Creek watershed. The landslides studied were in treeless residential developments. Slides averaged approximately $60 \mathrm{~m}$ in length and 45 $\mathrm{m}$ in width and created scarps from $1 \mathrm{~m}$ to $7 \mathrm{~m}$ high. The rockslides on steep slopes ( $>50 \%$ slope) and soil slides in the lower slopes $(<25 \%$ slope) were due to the large volume of water mov- 
ing through the colluviums, causing saturation and the loss of interparticle cohesion. In the Otter Creek watershed, colluvium is formed by weathering and erosion of the Fort Payne Formation (siltstone, shale, and chert with limestone lenses). The colluvium is composed of silt- to clay-sized silicates with fragments as large as boulders. During May 1-2, 2010, the rainfall records were broken with more than $43 \mathrm{~cm}$ of rainfall in the Otter Creek watershed (National Weather Service 2010). The rock and soil slides formed during May 1-2, 2010 in Radnor Lake State Natural Area are hydrogeomorphically similar to those described for the treeless developments studied by Miller and Wiethe (1975), except the slides occurred in dense forests (Loeb et al. 2010).

\section{Field Measurements}

During June 2010, field measurements were taken in all of the Radnor Lake State Natural Area landslides caused by the May 1-2, 2010 rainfall that felled and killed trees and saplings. Based upon the presence or absence of large rocks embedded in and bedrock exposed under the root plates, the landslides were divided into two groups: soil slides (no rock evident) or rockslides (rock visible). Diameter at breast height (DBH; $1.37 \mathrm{~m}$ height) was measured for the trees $(\mathrm{DBH} \geq 10 \mathrm{~cm})$ and saplings $(10 \mathrm{~cm}$ $>\mathrm{DBH}>2.5 \mathrm{~cm}$ ) that fell following the rainfall of May 1-2, 2010 and died as indicated by separation of the root mass from the ground and the leaves were brown. Percent slope was measured at each tree and sapling fall. Species were classified as having a surface root system, including red maple (Acer rubrum), sugar maple (Acer saccharum), common hackberry (Celtis occidentalis), sugarberry (Celtis laevigata), and willow (Salix spp.), versus tap root or heart root systems following Bernatzky (1978), Dirr (2009), and Wray (1997). There are several models which define the root plate (Coder 2010); however, none fit the situation of trees lost to landslides. The method used to measure the root plate diameter and root plate depth used by Gasson and Cutler (1990) in studying uprooted trees following an extraordinary gale is also appropriate for landslides. Root plate diameter was measured parallel to the scarp face to the extremity of the longest root exposed. Root plate depth was measured from the soil surface at the center of the stem to the endpoint of the longest exposed root aligned with the center of the stem.

\section{Statistical Analysis}

The data analyzed were tree and sapling stem counts by species; basal area; root plate diameter and root plate depth; and percent slope. Table 1 contains the rockslide and soil slide data for stems of trees and saplings by species, and results from the 2009 survey of Radnor Lake State Natural Area (Loeb et al. 2010). The survey used 194 plots with $8 \mathrm{~m}$ radius located in transects across the Natural Area including all the areas containing the rockslides and soil slides. The sapling and trees totals by species from the Natural Area survey were transformed with division by 22 and rounding to the integer to enable determination of significant differences from the soil slide and rockslide results by species and tree versus sapling using the chi square test. Basal area was calculated for all multiple stem and single stem trees to relate tree size to root plate diameter and root plate depth. For a few saplings and small trees embedded in the colluvium and root mass of much larger trees, root plate depth and diameter could

Table 1. Trees and saplings in soil slides, rockslides, and the Radnor Lake State Natural Area survey (Loeb et al. 2010). Natural Area survey results were transformed from the original totals with division by 22 and rounding to the integer value. An asterisk (*) indicates less than 11 saplings or trees were present in the Natural Area survey.

\begin{tabular}{|c|c|c|c|c|c|c|}
\hline \multirow[t]{2}{*}{ Species (common) } & \multicolumn{2}{|c|}{ Soil Slides } & \multicolumn{2}{|c|}{ Rockslides } & \multicolumn{2}{|c|}{ Natural Area Survey } \\
\hline & Saplings & Trees & Saplings & Trees & Saplings & Trees \\
\hline Acer negundo (boxelder) & 1 & 2 & 0 & 0 & 2 & 1 \\
\hline Acer rubrum (red maple) & 1 & 1 & 0 & 0 & $*$ & $*$ \\
\hline Acer saccharum (sugar maple) & 20 & 20 & 9 & 32 & 47 & 20 \\
\hline Ailanthus altissima (tree of heaven) & 0 & 1 & 0 & 5 & 10 & 1 \\
\hline Asimina trifolia (pawpaw) & 0 & 0 & 1 & 0 & 11 & 3 \\
\hline Carya glabra (pignut hickory) & 1 & 0 & 0 & 3 & 2 & 1 \\
\hline Carya ovata (shagbark hickory) & 1 & 5 & 0 & 6 & $*$ & $*$ \\
\hline Carya tomentosa (mockernut hickory) & 1 & 1 & 0 & 3 & * & $*$ \\
\hline Celtis occidentalis (common hackberry) & 1 & 18 & 2 & 26 & 2 & 4 \\
\hline Celtis laevigata (sugarberry) & 0 & 5 & 1 & 3 & $*$ & $*$ \\
\hline Fraxinus americana (white ash) & 3 & 15 & 0 & 13 & $*$ & 3 \\
\hline Juglans nigra (black walnut) & 0 & 2 & 0 & 2 & 0 & 1 \\
\hline Liriodendron tulipifera (tulip tree) & 0 & 1 & 0 & 1 & $*$ & $*$ \\
\hline Prunus avium (sweet cherry) & 1 & 4 & 0 & 3 & 0 & 0 \\
\hline Prunus serotina (black cherry) & 0 & 5 & 0 & 1 & 0 & $*$ \\
\hline Quercus alba (white oak) & 0 & 1 & 0 & 1 & $*$ & $*$ \\
\hline Quercus prinus (chestnut oak) & 0 & 2 & 0 & 4 & $*$ & 1 \\
\hline Quercus rubra (northern red oak) & 0 & 5 & 0 & 6 & * & 1 \\
\hline Quercus velutina (black oak) & 0 & 0 & 0 & 1 & * & 1 \\
\hline Robinia psuedoacacia (black locust) & 1 & 5 & 0 & 1 & * & 1 \\
\hline Sassafras albidum (sassafras) & 0 & 4 & 0 & 5 & $*$ & 1 \\
\hline Tilia americana (American basswood) & 1 & 1 & 0 & 3 & 2 & 1 \\
\hline Ulmus rubra (slippery elm) & 0 & 4 & 1 & 2 & 3 & 3 \\
\hline Additional species ${ }^{\mathrm{z}}$ & 0 & 2 & 0 & 1 & 7 & 7 \\
\hline Total & 32 & 106 & 14 & 124 & 86 & 52 \\
\hline
\end{tabular}

${ }^{\mathrm{z}}$ Additional species for rockslides: Salix spp. (willow); soil slides: Aesculus hippocastanum (horsechestnut); and Natural Area survey: Acer saccharinum (silver maple), Aesculus glabra (Ohio buckeye), Carya cordiformis (bitternut hickory), Cornus florida (flowering dogwood), Crataegus spp. (hawthorn), Diospyros virginiana (common persimmon), Fagus grandifolia (American beech), Gleditsia triacanthos (honeylocust), Juniperus virginiana (eastern redcedar), Morus alba (white mulberry), Ostrya virginiana (hophornbeam), Platanus occidentalis (American sycamore), Pyrus malus (European crabapple), Quercus bicolor (swamp white oak), and Ulmus americana (American elm). 
not be determined. Excluding the embedded trees and saplings, t-tests for differences among means as well as Pearson's product moment correlations were calculated for basal area, root plate diameter, root plate depth, and percent slope measurements using the classifications of soil slide or rockslide as well as surface root system species or tap and heart root systems species. The $\chi^{2}$ tests, Pearson's product moment correlation analysis, and ttests were performed using PASW Statistics (formerly SPSS Statistics) version 17 and the significance level selected was 0.05 .

\section{RESULTS}

\section{Species Composition Changes Following Landslides}

The $\chi^{2}$ test results did not reveal significant differences for species of trees and saplings among the rockslides, soil slides, and Natural Area survey. Sugar maple, common hackberry, and white ash had the first, second, and third highest number of trees, respectively, in the Natural Area survey as well as the rockslides and soil slides. The rockslides and soil slides had significantly more trees and fewer saplings than found in the Natural Area survey. Also, the soil slides had significantly more saplings and fewer trees than the rockslides (Figure 1). The numbers of sugar maple trees and saplings was equal in soil slides, but there were nearly four times as many trees as saplings in rockslides, which accounts for most of the difference between saplings and trees for rockslides and soil slides. The five taxa comprising the surface root system species (red maple, sugar maple, common hackberry, sugarberry, and willow) had slightly more tree and sapling stems than the 21 species with tap or heart root systems. The surface root system species comprised $74 \%$ of the saplings (Table 1).

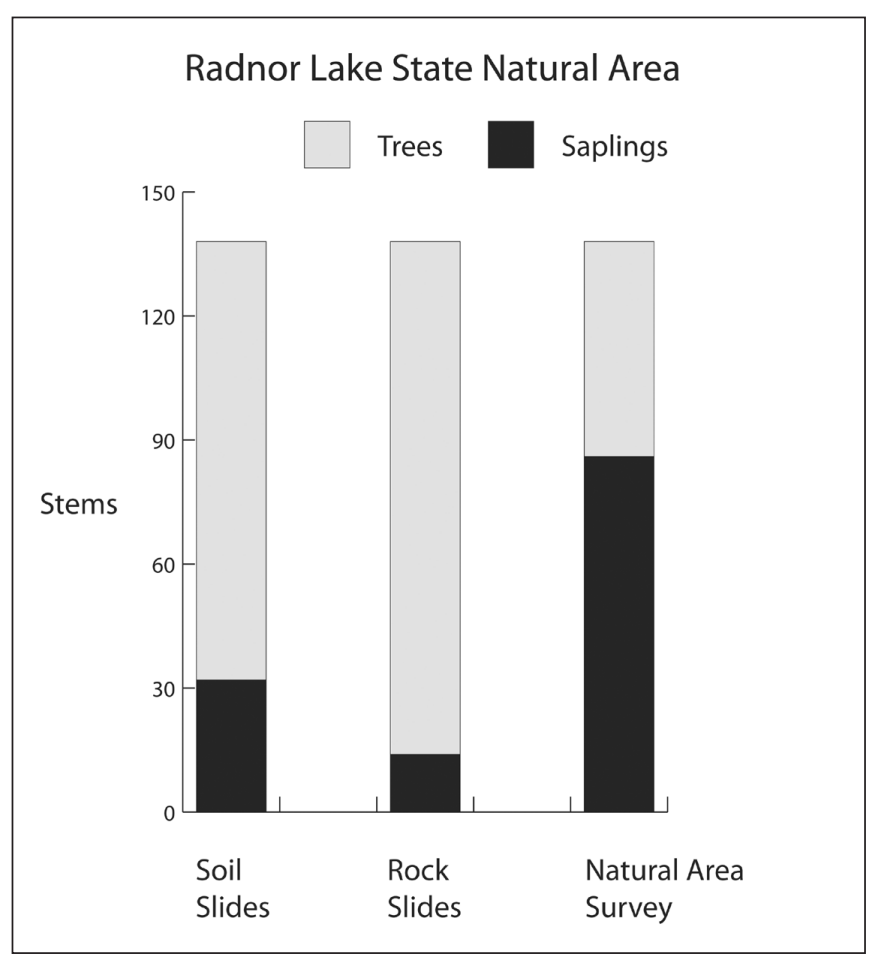

Figure 1. Trees and saplings in soil slides, rockslides, and Radnor Lake State Natural Area survey (Loeb et al. 2010). Natural Area survey results were transformed from the original totals with division by 22 .

\section{Root Plates Differences for Soil Slides and Rockslides}

The means for root plate diameter, root plate depth, and percent slope were significantly smaller for soil slides than rockslides; however, mean basal area was not significantly different between soil slides and rockslides (Table 2) even though there were more than twice as many saplings in soil slides than rockslides (Table 1). The linear correlations among basal area, root plate diameter, and root plate depth were significant for both rockslides and soil slides. In contrast, there were no significant linear correlations for basal area, root plate diameter, and root plate depth with percent slope for rockslides and soil slides (Table 3).

\section{Root System Type and Urban Landslides}

Basal area and root plate depth means were significantly smaller for the surface root systems species than tap and heart root systems species, but root plate diameter and percent slope means were not significantly different (Table 4). Each linear correlation analysis of basal area, root plate diameter, and root plate depth for surface root system species and tap and heart root systems species resulted in significant positive correlation coefficients. As might be expected, an increase in tree size is associated with an increase in root plate mass for the surface root system species as well as the tap and heart root system species. The correlation analysis of percent slope with basal area, root plate diameter, and root plate depth for surface root system species and tap and heart root systems species showed the results were not significant except for percent slope with root plate depth for tap and heart root systems species (Table 5).

Table 2. Means and standard deviations for basal area, root plate diameter, root plate depth, and percent slope for trees and saplings in rockslides and soil slides.

\begin{tabular}{lcccc}
\hline & \multicolumn{2}{c}{ Rockslides $(\mathrm{n}=124)$} & \multicolumn{2}{c}{ Soil slides $(\mathrm{n}=129)$} \\
& Mean & $\begin{array}{c}\text { Standard } \\
\text { deviation }\end{array}$ & Mean & $\begin{array}{c}\text { Standard } \\
\text { deviation }\end{array}$ \\
\hline Basal area $\left(\mathrm{dm}^{2}\right)$ & 14.6 & 13.7 & 12.2 & 13.6 \\
Root plate diameter $(\mathrm{m})$ & 3.8 & 2.4 & $3.1^{\mathrm{z}}$ & 1.8 \\
Root plate depth $(\mathrm{m})$ & 1.6 & 0.8 & $1.3^{\mathrm{z}}$ & 0.8 \\
Percent slope & 31.1 & 11.1 & $21.1^{\mathrm{z}}$ & 15.8 \\
\hline
\end{tabular}

${ }^{\mathrm{z}}$ Mean for soil slides is significantly $(<0.05$ level, two-tailed t-test with different numbers of samples and variances) smaller than mean for rockslides.

Table 3. Linear correlation coefficients for basal area, root plate diameter, root plate depth, and percent slope for trees and saplings in rockslides (below the center diagonal of the matrix) and soil slides (above the center diagonal of the matrix).

\begin{tabular}{lcccc}
\hline & Basal area & $\begin{array}{l}\text { Root plate } \\
\text { diameter }\end{array}$ & $\begin{array}{l}\text { Root plate } \\
\text { depth }\end{array}$ & $\begin{array}{l}\text { Percent } \\
\text { slope }\end{array}$ \\
\hline Basal area $\left(\mathrm{dm}^{2}\right)$ & & $0.70^{z}$ & $0.53^{z}$ & 0.05 \\
Root plate diameter $(\mathrm{m})$ & $0.59^{\mathrm{z}}$ & & $0.47^{\mathrm{z}}$ & -0.05 \\
Root plate depth $(\mathrm{m})$ & $0.59^{\mathrm{z}}$ & $0.50^{\mathrm{z}}$ & & -0.02 \\
Percent slope & 0.07 & -0.01 & 0.10 & \\
\hline
\end{tabular}

${ }^{\mathrm{z}}$ Correlation coefficient is significant $(<0.05$ level, two-tailed test $)$. 
Table 4. Means and standard deviations for basal area, root plate diameter, root plate depth, and percent slope for trees and saplings of surface root system species and tap and heart root systems species.

\begin{tabular}{lcccc}
\hline & \multicolumn{2}{l}{$\begin{array}{l}\text { Surface root systems } \\
\text { species }(\mathrm{n}=126) \\
\text { Mean }\end{array}$} & $\begin{array}{l}\text { Tap and heart root systems } \\
\text { Standard } \\
\text { deviation }\end{array}$ & $\begin{array}{l}\text { Mean }(\mathrm{n}=127) \\
\text { Standard } \\
\text { deviation }\end{array}$ \\
\hline Basal area $\left(\mathrm{dm}^{2}\right)$ & $9.5^{\mathrm{z}}$ & 9.7 & 17.3 & 15.8 \\
Root plate diameter $(\mathrm{m})$ & 3.3 & 2.2 & 3.5 & 2.1 \\
Root plate depth $(\mathrm{m})$ & $1.2^{\mathrm{z}}$ & 0.7 & 1.6 & 0.8 \\
Percent slope & 26.2 & 13.1 & 26.1 & 15.8 \\
\hline
\end{tabular}

${ }^{\mathrm{z}}$ Mean for surface root system species is significantly $(<0.05$ level, two-tailed t-test with different numbers of samples and variances) smaller than mean for tap and heart root systems species.

Table 5. Linear correlation coefficients for basal area, root plate diameter, root plate depth, and percent slope for trees and saplings of surface root system species (below the center diagonal of the matrix) and tap and heart root systems species (above the center diagonal of the matrix).

\begin{tabular}{lcccc}
\hline & Basal area & $\begin{array}{l}\text { Root plate } \\
\text { diameter }\end{array}$ & $\begin{array}{l}\text { Root plate } \\
\text { depth }\end{array}$ & $\begin{array}{l}\text { Percent } \\
\text { slope }\end{array}$ \\
\hline $\begin{array}{l}\text { Basal area }\left(\mathrm{dm}^{2}\right) \\
\text { Root plate diameter }(\mathrm{m})\end{array}$ & $0.74^{\mathrm{z}}$ & $0.63^{\mathrm{z}}$ & $0.51^{\mathrm{z}}$ & 0.15 \\
Root plate depth $(\mathrm{m})$ & $0.53^{\mathrm{z}}$ & $0.60^{\mathrm{z}}$ & $0.44^{\mathrm{z}}$ & 0.06 \\
Percent slope & -0.03 & 0.01 & -0.05 & $0.24^{\mathrm{z}}$ \\
\hline
\end{tabular}

${ }^{2}$ Correlation coefficient is significant $(<0.05$ level, two-tailed test).

\section{DISCUSSION}

\section{Species Composition Changes Following Landslides}

Do rockslides or soil slides change the species composition of trees and saplings in urban forests? The $\chi^{2}$ test results did not indicate a significant difference between the distribution of stems by species in the soil slides and the rockslides and the Natural Area survey. Duryea and colleagues (2007) reported the number of trees by species uprooted by hurricanes in Florida, U.S., was different from the populations of each species in the forests. Tree falls by species in parklands following a gale striking England on October 16, 1987, differed from the species composition of the parklands (Gibbs and Greig 1990). Both the Florida and England results indicate wind storms cause greater tree losses for some species than others while landslides do not differentially affect species composition as evidenced by the Radnor Lake State Natural Area information.

The significantly larger number of trees than saplings in both the soil slides and rockslides indicates that landslides cause more losses for trees than saplings (Figure 1). The root system of a sapling increases soil cohesion and reduces landslide events (Riestenberg 1994); however, no research is available to evaluate whether the far greater weight of a large tree, as compared to a sapling, becomes a significant contributing factor in landslides. Riestenberg (1994) demonstrated that saplings of the surface root system species sugar maple are less effective in enhancing soil cohesion than saplings of the tap root system species white ash. The greater losses for sugar maple saplings in soil slides could be related to the surface root system producing less root related soil cohesion, which also would explain why $74 \%$ of the saplings in the landslides were surface root systems species.

\section{Root Plates Differences for Soil Slides and Rockslides}

Are the diameter and depth of the root plate different for urban trees killed in soil slides versus rockslides? The presence of rock, including bedrock, is an impediment to the spread of roots. For similar size trees, root systems in rocks are expected to be longer and deeper to obtain the equal amounts of water and nutrients as gained by root systems in soil (Sidle and Ochiai 2006). The significant correlations provide support for the relationship of root plate mass increasing with tree basal area through the range of tree sizes (Coder 2010; Day et al. 2010). The lack of significant correlations with slope indicates: 1) slope steepness does not influence the distribution of trees by stem size, which conflicts with research on influence of slopes on landslides in rural forests $(\mathrm{Wu}$ and Chen 2009); and 2) root plate size is not related to the angle of slope, which differs from research on the influence of steep slopes on root system development (Chiatante et al. 2003). The prior research (Chiatante et al. 2003; Wu and Chen 2009) has been focused on saplings and small trees, but as a tree ages the weight of the tree becomes the predominant factor in tree anchorage rather than primarily root strength (Coder 2010). Also, the far greater weight of large trees in extraordinary rainfall situations would increase the risk of colluvium landslides (Koi et al. 2006).

Although extensive research on root plates has been performed in many countries, the science is still in the early stages of development and no work has been done on root plates in relationship to landslides. One point concerning the data in this study that should be emphasized is the measurement of the root plate as the maximum extremity of exposed roots does not fit the concepts of what is measured in the common models of the relationship between stem basal area and root plate diameter and root plate depth (Coder 2010). A second point of emphasis is that no attempt was made to excavate the many roots broken during the landslides, because excavations are prohibited in the Natural Area. Therefore, no attempt has been made to ascertain if the observed relationships at the landslides fit the models. Measurements of root plate diameter and root plate depth for trees felled by the gale that struck England in October 1987 did not show a pattern of increasing root plate depth or diameter with increasing tree $\mathrm{DBH}$, but the explanation was suggested that historical planting practices may have influenced root plate development (Gibbs and Greig 1990).

\section{Root System Type and Urban Landslides}

Are surface root systems species affected differently than species with tap root and heart root systems in urban landslides? Losses for surface root system species were not greater than losses for tap and heart root system species among the landslides in the Natural Area. A survey of downed trees following the gale striking England in October 1987 showed that lateral root system and lateral root system species with droppers comprised more than $81 \%$ of the 4,511 trees measured. The high percentage was interpreted in two ways: 1) as evidence that tap root trees typically survived the storm or 2) many of the 4,511 trees lost their tap roots as a result of transplantation. Either interpretation supports the practice of preserving the tap root during urban tree plantings in windstorm prone areas (Cutler et al. 1990; Gasson and Cutler 1990). 
The tap and heart root systems species appear to have grown larger because of greater root plate depth, while root plate diameters approximated the size of smaller DBH surface root system species. Notes of caution are warranted before generalizing from the species classification as surface root system or tap root and heart root systems following Bernatzky (1978), Dirr (2009), and Wray (1997). First, the tendency of an individual tree to follow the pattern of a root system is modified by the particular growing conditions (Bernatzky 1978). For example, when bedrock limits root depth, the root plate of a tree has a larger diameter and shallower depth than trees growing in conditions without root depth limitations (Coutts et al. 1999). Second, the significant root plate depth correlation with slope could be explained by the water table, which is a limiting factor for root depth, being farther from the soil surface in steep slopes than in moderate slopes (Chiatante et al. 2003).

A study of colluvium covered slopes in the Cincinnati, Ohio, U.S., area showed that saplings of the tap root system species white ash could stabilize soil as thick as $1 \mathrm{~m}$ while sugar maple saplings with a lateral root system could not stabilize soil thicker than 0.5 $\mathrm{m}$ (Riestenberg 1994). Tap roots provide greater depth of anchoring for the root network; however, tap roots of both broadleaf and conifer species lose importance in regard to tree stability relative to the spread of lateral roots as a tree ages (Chiatante et al. 2003).

\section{CONCLUSIONS AND IMPLICATIONS}

The urban trees in Radnor Lake State Natural Area were not differentially affected by landslides in regard to species, slide type (soil slide or rockslide), slope steepness, or root system type (surface root system versus tap or heart root system), but saplings are lost much less frequently than trees-including fewer saplings lost in rockslides than soil slides. Management of urban areas with hydrogeomorphic landslides should be based on landslide history to identify locales of special concern and to prioritize sites for tree plantings since landslide recurrence at a site is unlikely for decades or at least until a sufficient mass of colluvium redevelops (Koi et al. 2006). The relationships found for root plate diameter and root plate depth indicate rooting characteristics are a critical aspect to consider during species selection for tree plantings to reduce the risk of landslides in urban areas. Because tap root trees produce more depth in the root cohesion network, tap root trees should be preferred for planting to ameliorate the risk of rockslides or soil slides (Riestenberg 1994). Planting tap root trees is a challenge for arboriculturalists because traditional methods of transplantation do not accommodate fast growing tap roots well. A focus on developing better methods for cultivating species of Carya for preservation of the taproot during transplantation (Dirr 2009) could create the means to supply a market for landslide prone areas. In planning for plantings, spacing of no more than $7 \mathrm{~m}$ apart is needed for the development of overlapping root networks that provide soil cohesion across an area (Riestenberg 1994). If the soil or growing conditions of the site are not uniform, then closer spacing or placement to adjust for subsurface impediments is essential (Riestenberg 1994). In addition to tree density, the extent of root cohesion is dependent upon the species assemblage at a site because of local variability in root cohesion within a stand (Schmidt et al. 2001). Finally, consideration must be given to site conditions such as soil depth, bedrock geology, and water table elevation to increase the likelihood of transplanta- tion success for plantings to reduce landslide risk. When feasible, modifications of a site to eliminate limiting conditions can be done to enhance tree growth and stabilize landslide-prone urban areas.

Acknowledgments. The authors acknowledge the contributions of Steve Ward, Park Manager; Jesse Germeraad, Interpretative Ranger and the staff at Radnor Lake State Natural Area; as well as Kent Gallaher, Chair and Bonnie Gallagher, Undergraduate Student of the Department of Biology at Lipscomb University. We appreciate the review of a draft manuscript provided by Naomi Burnell, Alexandra Gren, Patience McCullough, Antoni Pelc, and Jericha Skuntz of The Pennsylvania State University.

\section{LITERATURE CITED}

Bernatzky, A. 1978. Tree Ecology and Preservation. Elsevier, New York. $357 \mathrm{pp}$.

Braun, E.L. 1950. Deciduous Forests of the Eastern North America. Hafner, New York. 596 pp.

Chiatante, D., S.G. Scippa, A. Di Iorio, and M. Sarnataro. 2003. The influence of steep slopes on root system development. Journal of Plant Growth Regulation 21:247-260.

Coder, K.D. 2010. Root strength and tree anchorage. Warnell School Outreach Monograph WSFNR 10-19. 88 pp.

Coutts, M.P., C.C.N. Nielsen, and B.C. Nicoll. 1999. The development of symmetry, rigidity, and anchorage in the structural root system of conifers. Plant \& Soil 217:1-15.

Cutler, D.F., C.C.N. Nielsen, and M.C. Farmer. 1990. The windblown tree survey: analysis of the results. Arboricultural Journal 14:265-286.

Day, S.M., P.E. Wiseman, S.B. Dickinson, and J.R. Harris. 2010. Contemporary concepts of root system architecture of urban trees. Arboriculture \& Urban Forestry 36:149-159.

Dirr, M. 2009. Manual of Woody Landscape Plants: Their Identification, Ornamental Characteristics, Culture, Propagation and Uses. Stipes Publishing, Champaign, IL. 1325 pp.

Duryea, M.L., E. Kampf, and R.C. Littell. 2007. Hurricanes and the urban forest: 1. Effects on southeastern United States coastal plain tree species. Arboriculture \& Urban Forestry 33:83-97.

Gasson, P.E., and D.F. Cutler. 1990. Tree plate morphology. Arboricultural Journal 14:193-264.

Gibbs, J.N., and B.J.W. Greig. 1990. Survey of parkland trees after the great storm of October 16, 1987. Arboricultural Journal 14:321-347.

Greenway, D.R. 1987. Vegetation and slope stability, pp. 187-230. In: M.G. Anderson and K.S. Richards (Eds.). Slope Stability. John Wiley and Sons, Chichester, UK.

Johnson, A.C., and P. Wilcock. 2002. Association between cedar decline and hillslope stability in mountainous regions of southeast Alaska. Geomorphology 46:129-142.

Koi, T., N. Hotta, and M. Suzuki. 2006. Sediment yield and vegetation recovery in a mountainous region with repeated heavy precipitation $-\mathrm{A}$ case study in the Omaru River Basin, Miyazaki, Japan, pp. 321-329. In: H. Marui, T. Marutani, N. Watanabe, H. Kawabe, Y. Gonda, M Kimura, H. Ochiai et al. (Eds.). Disaster Mitigation of Debris Flows, Slope Failures and Landslides. Frontiers of Science Series, v. 47, Universal Academy Press, Tokyo, Japan.

Loeb, R.E., J. Germeraad, T. Treece, D. Wakefield, and S. Ward. 2010. Effects of one-year versus annual treatment of Amur honeysuckle in forests. Invasive Plant Science and Management 3:334-339.

McNaughton, K.G., and P.G. Jarvis. 1983. Predicting effects of vegetation changes on transpiration and evaporation, pp. 1-47. In: T.T. Kozlowski (Ed.). Water Deficits and Plant Growth, v. 7. Academic Press, New York. 
Miller, R.A., and J.D. Wiethe. Landslides in the Nashville Tennessee Area - Winter 1975. Environmental Geology Series No. 3, Division of Geology, Department of Conservation, State of Tennessee, Nashville, TN. 15 pp.

National Weather Service. 2010. May 1 \& 2, 2010 Epic Flood Event for Western and Middle Tennessee. <http://www.srh.noaa.gov/ ohx/?n=may2010epicfloodevent $>$

Perret, S., F. Dolf, and H.H. Kienholz. 2004. Rockfalls into forests: Analysis and simulation of rockfall trajectories - Considerations with respect to mountainous forests in Switzerland. Landslides 1:123-130.

Riestenberg, M.M. 1994. Anchoring of Thin Colluvium by Roots of Sugar Maple and White Ash on Hillslopes in Cincinnati. United States Geological Survey Bulletin 2059-E. 25 pp.

Sakals, M.E., J.L. Innes, D.J. Wilford, R.C. Sidle, and G.E. Grant. 2006. The role of forests in reducing hydrogeomorphic hazards. Forest Snow Landscape Research 80:11-22.

Schmidt, K.M., J.J. Roering, J.D. Stock, W.E. Dietrich, D.R. Montgomery, and T. Schaub. 2001. The variability of root cohesion as an influence on shallow landslide susceptibility in the Oregon Coast Range. Canadian Geotechnical Journal 38:995-1024.

Sidle, R.C., and H. Ochiai. 2006. Landslides: Processes, Prediction, and Land Use. American Geophysical Union Water Resources Monographs $18.350 \mathrm{pp}$.

Wray, P. 1997. Tree Roots. <http://extension.iastate.edu/pages/tree/roots. html>

Wu, C., and S. Chen. 2009. Determining landslide susceptibility in central Taiwan from rainfall and six site factors using the analytical hierarchy process method. Geomorphology 112:190-204.

Robert E. Loeb (corresponding author)

Associate Professor

Department of Biology and Forestry

The Pennsylvania State University DuBois Campus

DuBois, PA 15801, U.S.

RXL5@PSU.EDU

Samuel King

Undergraduate Student

Department of Biology

Lipscomb University

Nashville, TN 37204, U.S.

Résumé. Des arbres et des semis ont été renversés et tués par les éboulements de rochers et les glissements de terrain qui se sont produits lors des pluies records du 1er et du 2 mai 2010 dans la Réserve naturelle d'état de Radnor Lake à Nashville au Tennessee (États-Unis). Les pertes ont été analysées en fonction des espèces, de la surface terrière, du diamètre et de l'épaisseur de la couche de racines, du pourcentage de pente, du degré d'occurrence des éboulements et des glissements de terrain, et de la classification de l'espèce en fonction de son type de système racinaire (système racinaire latéral versus pivot racinaire ou racines profondes). Le nombre de tiges perdues pour chacune des espèces avait une distribution similaire aux résultats contenus dans l'inventaire de 2009 de ce site, mais le nombre de semis était significativement sous-représenté dans les sites de glissement. La mortalité en arbres était près de cinq fois supérieure à celle des semis perdus. Même s'il y avait pratiquement des nombres équivalents d'arbres et de semis possédant un système racinaire latéral par rapport à ceux ayant un pivot racinaire ou des racines en profondeur, $74 \%$ des pertes en semis provenaient d'espèces à système racinaire en surface. Les diamètres et épaisseurs moyens de couches de racines étaient significativement plus élevés dans les zones d'éboulement que dans les zones de glissement de sol, et ce même si la surface terrière ne différait pas significativement. Dans les deux types de mouvements de terrain, l'inclinaison de la pente n'était pas corrélée avec l'épaisseur ou le diamètre de la couche de racines, ou la surface terrière. Similairement, pour les deux types de système racinaire, l'inclinaison de la pente n'était pas significativement corrélée avec l'épaisseur de la couche de racines. La plantation d'arbres à pivot racinaire diminue les risques de mouvement de terrain, mais des progrès dans la culture de taxons, tels ceux de caryer (Carya spp.), sont requis pour assurer la préservation du pivot racinaire durant le processus de transplantation.

Zusammenfassung. Durch Fels- undErdrutsche wurden während der rekordbrechenden Regenfälle am 1. und 2. Mai 2010 in Radnor Lake State Natural Area, Nashville, Tennessee, U.S. Bäume und Triebe gefällt und zerstört. Die Verluste wurden analysiert anhand von Baumart, Stammdurchmesser, Wurzeltellerdurchmesser und Tiefe, Neigungsgrad, Erd- oder Felsrutsch und artentypische Klassifikationen wie laterales Wurzelsystem oder Herzwurzler-Arten. Die Anzahl der verlorenen Stämme pro Baumart hatte eine ähnliche Verteilung wie die Ergebnisse der Flächeninventur in 2009, aber die Anzahl der Jungtriebe war deutlich unterrepräsentiert auf den Erdrutschflächen. Die Verlustrate der Bäume war fast fünffach so hoch wie der Verlust der Jungtriebe. Obwohl ca. Gleiche Anzahl von Bäumen und Trieben, die als Lateral- oder Herzwurzler klassifiziert waren, lagen die Verluste der Oberflächenwurzler bei den Jungtrieben bei $74 \%$. Der Durchschnitt der Wurzeltellerdurchmesser und Tiefe war auf den Flächen mit Felsrutschen deutlich höher als bei Erdrutschen, obwohl die durchschnittliche Stammgröße nicht deutlich abwich. Für beide Rutschformen war die Hangneigung nicht korreliert mit der Wurzeltellertiefe, dem Wurzeltellerdurchmesser oder der Stammbasisfläche. Für beide Wurzelsysteme war die Hangneigung nicht besonders signifikant, außer bei oberflächigen Wurzelsystemen mit Wurzeltellertiefe. Die Pflanzung von Tiefwurzlern reduziert die Gefahr von Erdrutschen aber es sind Fortschritte in der Kultivation von Arten wie Hickory (Carya spp.) nötig, um zu sichern, daß die zentrale Wurzel nicht bei der Tranplatantion beschädigt wird.

Resumen. Árboles y brinzales cayeron y murieron en las laderas y deslaves de suelos formados durante las lluvias registradas de Mayo 1-2, 2010, en el Área Natural de Radnor Lake State, Nashville, Tennessee, U.S. Se analizaron las pérdidas por especie, área basal, diámetro de la corona y profundidad de la raíz, porciento de pendiente, ocurrencia en la ladera o suelo, así como clasificación de especies con especies de sistema de raíces laterales contra especies de sistemas de raíz pivotante. El número de tallos perdidos por cada especie tiene una distribución similar a los resultados del censo del Área Natural en 2009 pero el número de brinzales estuvo subrepresentado en los sitios de ladera. Los árboles muertos fueron aproximadamente cinco veces más grandes que los brinzales. Aunque aproximadamente igual número de árboles y brinzales clasificados con sistema de raíces laterales contra raíces pivotantes, 74\% de las pérdidas de brinzales fueron de sistemas de raíces superficiales. Las medias para el diámetro de la corona y profundidad fueron significativamente mayores en las laderas de roca que en las de suelo aunque la media de área basal no difirió significativamente. Para ambos tipos de laderas, el ángulo de la ladera no estuvo correlacionado con la corona de la raíz, profundidad o área basal. Similarmente, para ambas clasificaciones de sistemas de raíz, la agudeza de la ladera no estuvo significativamente correlacionada con profundidad de raíz, excepto para para árboles con sistema de raíz superficial. La plantación de árboles con sistema de raíz pivotante reduce el riesgo de ladera, pero se requieren avances en el cultivo de taxa, tales como Carya spp., para asegurar la preservación de la raíz pivotantes durante el trasplante. 